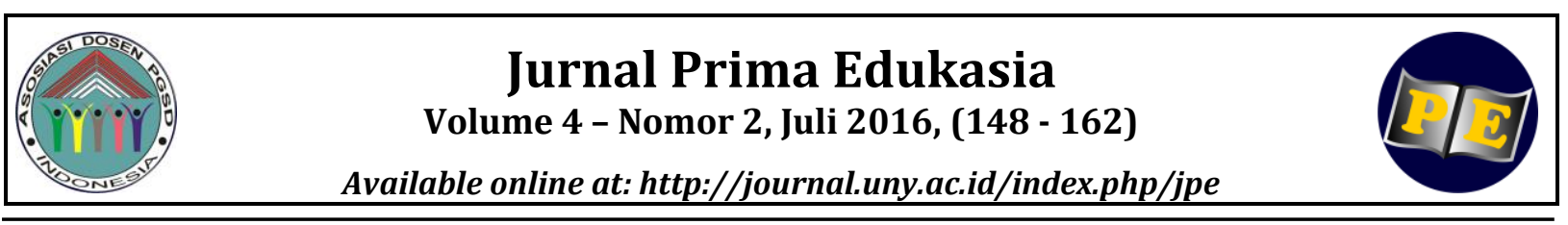

\title{
PENINGKATAN KEAKTIFAN DAN PEMAHAMAN KONSEP IPS MELALUI MODEL LEARNING CYCLE 5E
}

\author{
Laila Fatmawati \\ Pendidikan Guru Sekolah Dasar, FKIP, Universitas Ahmad Dahlan Yogyakarta. Jalan Ki Ageng \\ Pemanahan No.19, Sorosutan,Yogyakarta, Indonesia \\ Email: lailaokyfatmawati@gmail.com
}

\begin{abstract}
Abstrak
Penelitian ini bertujuan meningkatkan keaktifan dan pemahaman konsep IPS dengan menggunakan model learning cycle 5E. Tahapan learning cycle $5 E$ meliputi engagement, exploration, explanation, elaboration, evaluation. Subjek penelitian adalah mahasiswa PGSD UAD kelas D yang berjumlah 46 mahasiswa. Penelitian ini merupakan penelitian tindakan kelas (classroom action research). Penelitian berlangsung dalam dua siklus, setiap siklus terdiri atas empat tahap yaitu perencanaan, pelaksanaan, observasi, dan refleksi. Teknik pengumpulan data yang digunakan meliputi: observasi, tes hasil belajar, wawancara, catatan lapangan, serta studi dokumentasi. Data yang terkumpul dianalisis secara kualitatif dengan mengacu pada model Miles \& Hubberman, dan kuantitatif berbantuan SPSS. Hasil penelitian menunjukkan adanya peningkatan keaktifan dan pemahaman konsep IPS pada mahasiswa dengan menggunakan model learning cycle $5 E$.
\end{abstract}

Kata Kunci: learning cycle, keaktifan, pemahaman konsep IPS.

\section{INCREASING THE ACTIVENESS AND UNDERSTANDING OF SOCIAL STUDIES CONCEPT THROUGH LEARNING CYCLE}

\begin{abstract}
This research aims to improve the activeness and understanding of social studies concept through learning cycle with 5e. Steps of learning cycle with 5 e consist of engagement, exploration, explanation, elaboration, evaluation. The subject is college students of class $D$ of the Elementary School Education Department, Ahmad Dahlan University who are 46 students. This research is a classroom action research. This research has two cycles. Each cycle consists of four stages which are planning, implementation, observation, and reflection. Data collection used observation sheets, tests, interviews, field notes, and documentation study. The collected data was analyzed used qualitative referred to Miles \& Hubberman model, and quantitative assisted by SPSS. The result of the research is the college students' activeness has increased through learning cycle with $5 e$.
\end{abstract}

Keywords: learning cycle, activeness, understanding social studies concept.

How to Cite: Fatmawati, L. (2016). Peningkatan keaktifan dan pemahaman konsep IPS melalui model learning cycle 5E. Jurnal Prima Edukasia, 4(2), 148-162. doi:http://dx.doi.org/10.21831/jpe.v4i2.9488

Permalink/DOI: http://dx.doi.org/10.21831/jpe.v4i2.9488 


\section{Pendahuluan}

Kualitas kehidupan suatu bangsa, tercermin dari kualitas pendidikannya. Semakin baik kualitas pendidikan, semakin baik pula kualitas sumber daya manusianya, sehingga kualitas kehidupan masyarakat pun semakin meningkat. Saat ini, permasalahan pendidikan di Indonesia menjadi fokus utama pemerintah. Indeks pembangunan pendidikan Indonesia setiap tahunnya semakin menurun. Tahun 2012 yang lalu, UNESCO mengeluarkan data indeks pembangunan pendidikan atau education development index (EDI), menempatkan Indonesia pada posisi 69 dari 127 negara. Indeks ini memposisikan Indonesia lebih rendah 4 peringkat dibandingkan Malaysia yang menduduki peringkat 65. (Rendik Setiawan pada laman web http://kampus.okezone.com/read/2012/10/23/37 3/708090/indeks-pendidikan-ri-rendah-jangansalahkan-mendikbud). Hasil education development index (EDI) ini menjadi cerminan betapa kualitas pendidikan di negeri ini masih kalah bersaing dengan negara-negara lain. Masalah pendidikan di Indonesia apabila tidak segera diperbaiki, akan menyebabkan Indonesia tidak akan mampu menjawab tantangan globalisasi.

Salah satu cara memperbaiki mutu sumber daya manusia dengan melakukan pembenahan kualitas pendidikanan. Langkah awal yang perlu dilakukan adalah meningkatkan kualitas calon pendidik. Melalui peningkatan kualitas para calon pendidik, diharapkan mampu menghasilkan peserta didik yang berkualitas pula. Peran LPTK (Lembaga Pendidikan Tinggi Kependidikan) sebagai garda terdepan pencetak calon-calon pendidik profesional tentunya menentukan keberhasilan peningkatan kualitas lulusannya.

Fakultas Keguruan dan Ilmu Pendidikan (FKIP), UAD sebagai salah satu LPTK yang memiliki kontribusi besar menghasilkan tenaga kependidikan profesional mulai dari tingkat PAUD hingga tingkat SMA. Salah satu program studi yang akan mencetak calon tenaga guru adalah Prodi PGSD yang memfokuskan diri membekali pengetahuan, keterampilan, sikap pada mahasiswa agar bisa menjadi calon pendidik sekolah dasar yang profesional.

Sebagai calon guru sekolah dasar, mahasiswa PGSD UAD dibekali berbagai materi perkuliahan yang menunjang kompetensi profesional keguruan. Sebagaimana diungkapkan oleh Wahyudi (2012, p.31) kompetensi profesional adalah kemampuan guru dalam menguasai materi pembelajaran secara luas dan mendalam sehingga memungkinkan dalam membimbing dan mengarahkan peserta didik memenuhi standar kompetensi yang diharapkan.

Upaya untuk menumbuhkan kompetensi professional dengan membekali mahasiswa tentang materi keilmuan yang ada di SD, salah satunya yaitu mata kuliah materi pembelajaran IPS SD. Mata kuliah materi pembelajaran IPS SD merupakan mata kuliah yang membahas tentang materi-materi IPS yang diajarkan di tingkat SD. Kajian perkuliahan bersifat kontekstual mulai dari lingkungan sosial yang paling dekat dengan mahasiswa hingga lingkup global, isu-isu sosial dan fenomena sosial yang terjadi dalam kehidupan masyarakat.

Mahasiswa sebelum terjun untuk praktek mengajar IPS di SD, hendaknya sudah memahami seluruh materi IPS agar memiliki bekal keilmuan yang kuat untuk diajarkan pada peserta didik. Namun pada kenyataannya masih banyak mahasiswa PGSD pemahaman materi IPS mahasiswa masih rendah. Hal ini ditunjukkan dari rendahnya nilai hasil UTS dan UAS pada mata kuliah materi pembelajaran IPS SD.

Dari hasil pra penelitian yang dilakukan peneliti, nilai hasil UTS dan UAS mahasiswa PGSD yang mengambil mata kuliah materi pembelajaran IPS SD belum optimal. Data yang diperoleh dari 110 orang mahasiswa, 17 di antaranya mendapat nilai yang tidak mencapai KKM (65) untuk UTS, dan 59 orang mahasiswa yang mendapat nilai di bawah KKM (65) untuk UAS. Bila dihitung dalam persen, maka ada $15,45 \%$ mahasiswa yang mendapat UTS dan $53,6 \%$ mahasiswa yang UAS.

Faktor pemicu rendahnya hasil nilai UTS dan UAS mata kuliah materi pembelajaran IPS pada mahasiswa PGSD UAD yaitu keaktifan mahasiswa yang masih rendah. Keaktifan mahasiswa dalam belajar sangat menentukan keberhasilan pencapaian tujuan pembelajaran. Menurut Mulyasa (2005: 23), "pembelajaran dapat dikatakan berhasil dan berkualitas apabila seluruhnya atau setidak-tidaknya sebagian besar (70\%) peserta didik terlihat secara aktif, baik fisik, mental maupun sosial dalam proses pembelajaran, di samping menunjukkan kegairahan belajar yang tinggi, semangat belajar yang besar, dan rasa percaya diri sendiri".

Hasil pra penelitian menunjukkan proses pembelajaran yang berlangsung tidak mencerminkan proses pembelajaran yang aktif. Hal ini terlihat selama proses perkuliahan, keaktifan mahasiswa dalam mengikuti diskusi kelompok 
sangat rendah. Mereka kurang antusias memperhatikan materi-materi IPS yang disajikan temannya ketika presentasi nakalah kelompok.

Untuk memecahkan masalah rendahnya keaktifan dan tingkat pemahaman mahasiswa tentang konsep IPS, dosen sebagai fasilitator harus mencari model pembelajaran yang efektif. Salah satu model pembelajaran yang dapat digunakan untuk menyelesaikan adalah dengan menerapkan model learning cycle.

Learning cycle atau yang biasa dikenal dengan pembelajaran siklus merupakan salah satu model pembelajaran yang berpusat pada keaktifan mahasiswa. Model learning cycle ini menerapkan teori belajar konstruktivisme yaitu membimbing mahasiswa untuk aktif membangun sendiri pengetahuannya melalui kegiatan diskusi kelompok untuk menemukan hipotesis suatu konsep serta mampu menerapkan konsep yang telah diperolehnya dalam situasi baru untuk menyelesaikan soal di dalam kelompok. Dalam learning cycle ini terdapat tahapan yang memungkinkan terjadinya interaksi antara mahasiwa dengan teman sebayanya dalam mengembangkan pengetahuan. Interaksi yang terjalin melalui proses kerja sama menungkinkan mahasiswa dapat mencapai apa yang tidak mungkin dia capai jika hal tersebut dilakukan secara individu. Efek dari learning cycle dapat meningkatkan prestasi belajar, kemampuan dalam mengingat konsep yang lebih baik, meningkatkan sikap ilmiah, serta meningkatkan keterampilan proses dan daya nalar (Sole \& Wilujeng. 2013).

Abruscato \& DeRosa (2010) mengemukakan bahwa learning cycle adalah sebuah model pembelajaran yang mengarahkan seseorang untuk menemukan pengetahuan baru, melalui lima 5 tahap yaitu: engagement, exploration, explanation, elaboration, evaluation. Tahap awal dari learning cycle adalah tahap engagement atau tahap pembangkitan minat. Pada tahap ini tugas dosen adalah merangsang minat dan rasa ingin tahu mahasiswa tentang materi yang akan dipelajari. Dosen mengajukan beberapa pertanyaan pada mahasiswa tentang fenomena dalam kehidupan sehari-hari yang berhubungan dengan materi yang akan dipelajari. Dari respon atau jawaban mahasiswa akan digunakan dosen untuk mengetahui pengetahuan awal mereka. Kegiatan yang dilakukan pada tahap ini digunakan oleh dosen sebagai alat untuk mengidentifikasi miskonsepsi pemahaman mahasiswa (Wenna.2009, p.171).
Tahap exploration, mahasiswa dibagi dalam kelompok-kelompok kecil yang terdiri atas 5-6 orang, kemudian diberi kesempatan untuk berdiskusi secara aktif tentang permasalahan terkait materi yang dipelajari. Mahasiswa saling bertukar gagasan dan pendapat, kemudian berlatih membuat hipotesis baru dan mencoba mencari alternatif pemecahan masalah, melakukan dan mencatat pengamatan tentang ide yang berkembang dalam diskusi (Wenna, 2009, p.171).

Tahap explanation, dosen berperan sebagai fasilitator pembelajaran dan mendorong siswa untuk menemukan gagasan. Mahasiswa diminta untuk merekam pengamatan dan mengorganisasikan data yang telah diperoleh (Chiappetta \& Koballa, 2010, p.129).

Pada tahap explanation, mahasiswa didorong untuk berani mempresentasikan suatu konsep yang diperoleh melalui diskusi kelompok menggunakan bahasanya sendiri. Dengan adanya presentasi, mahasiswa akan menjadi lebih aktif dalam proses pembelajaran. Kegiatan pada tahap ini bertujuan untuk mengklarifikasi, menyempurnakan, dan mengembangkan konsep yang telah diperoleh. Dosen merangsang mahasiswa dengan pertanyaan yang mengarahkan mereka untuk berpikir kritis, serta menyempurnakan hasil presentasi mahasiswa. Pada tahap explanation, sangat diperlukan adanya diskusi antar anggota kelompok untuk mengkritisi pemaparan konsep dari mahasiswa yang satu dengan mahasiswa yang lain. Hal ini bermanfaat untuk meningkatkan pemahaman konsep yang telah diperoleh.

Pada tahap elaboration, mahasiswa menerapkan konsep dan keterampilan yang mereka peroleh pada situasi yang berbeda. Hal ini dapat membuat pembelajaran lebih bermakna. Kerja kelompok atau tugas mandiri dapat digunakan pada fase ini.

Pada tahap akhir yaitu evaluation, dosen melakukan evaluasi dengan memberikan kuis yang dikerjakan secara individu. Dari evaluasi ini dosen dan mahasiswa dapat mengetahui kekurangan dan kemajuan proses pembelajaran yang sudah dilakukan. Kegiatan tahap ini berhubungan dengan penilaian kelas yang meliputi penilaian proses dan evaluasi penguasaan konsep yang diperoleh mahasiswa dari tahaptahap sebelumnya (Wenna.2009, p.171).

Dari paparan tersebut, model pembelajaran learning cycle $5 \mathrm{E}$ dapat digambarkan seperti Gambar 1. 


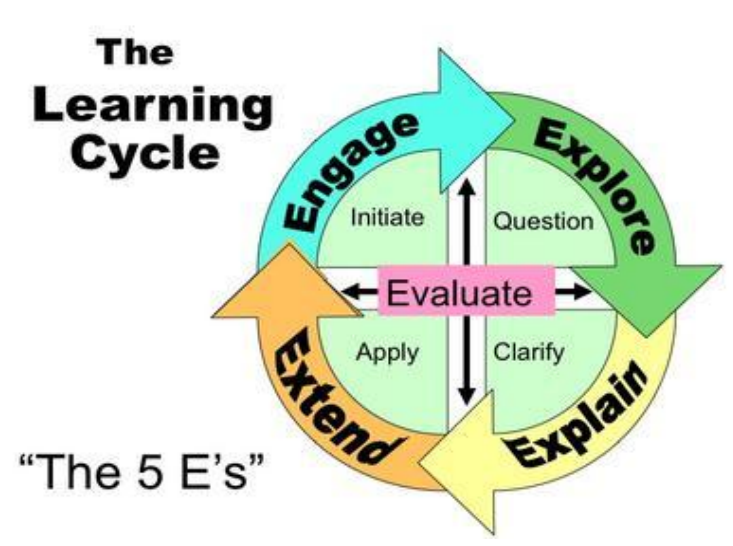

Gambar 1. Learning Cycle 5 E (Sumber:http://smartideas.wikispaces.com/Acti vity+Two)

Pemilihan model learning cycle didasarkan atas beberapa alasan, alasan yang pertama model learning cycle bersifat komprehensif dengan mengkombinasikan berbagai metode. Kedua, learning cycle memberikan kesempatan kepada mahasiswa untuk mengaitkan informasi yang baru dengan struktur kognitif yang telah dimilikinya sehingga pembelajaran akan lebih bermakna. Ketiga, model ini memberikan peluang kepada mahasiswa untuk melatih keterampilan higher order thinking dengan belajar menemukan sendiri konsep dari suatu pelajaran. Keempat, model ini berpusat pada aktivitas mahasiswa. Kelima, model ini berbentuk siklus jadi apabila ada konsep yang belum dipahami maka dapat dilakukan siklus ulang sampai tercapai ketuntasan belajar yang diharapkan (Susanto, Maftukhin, Ngazizah. 2014, p.45).

Setiap model pembelajaran memiliki keunggulan tersediri, begitu pula dengan model learning cycle. Adapun keunggulan dari learning cycle ini antara lain: (1) meningkatkan motivasi dan keaktifan mahasiswa dalam proses pembelajaran, (2) membantu mengembangkan sikap ilmiah mahasiswa, (3) pembelajaran menjadi lebih bermakna, (4) pembelajar menjadi lebih efektif, (5) meningkatkan kreatifitas dosen dalam merancang dan melaksanakan proses pembelajaran sehingga pembelajaran tidak terkesan teacher center (Saputra, Wiyasa, \& Ardana. 2014).

Beberapa hasil penelitian sebelumnya telah menunjukkan bukti bahwa pembelajaran learning cycle mampu membantu mahasiswa untuk meningkatkan pemahaman tentang suatu konsep secara mendalam. Hal ini sejalan dengan pendapat yang dikemukakan oleh Bybee (2006, p.28) "a significant line of research shows that learning cycle-based teaching approaches help student develop deep understanding". Selain itu berdasarkan hasil penelitian Johnson and Lawson yang dikutip oleh Bybee (2006, p.28) mengemukakan bahwa "learning cycle-based teaching had a statistically significant positive on the scientific reasoning". Menurut hasil penelitian Johnson and Lawson, learning cycle memberikan dampak positif yang signifikan pada proses penalaran ilmiah. Dipertegas lagi oleh Bybee (2006, p.43) " $5 E$ instructional model is more effective for improving student achievement when the teacher uses the curriculum materials the way they were developed". Hal ini berarti model pembelajaran $5 \mathrm{E}$ lebih efektif untuk meningkatkan hasil belajar mahasiswa ketika dosen menggunakan materi berdasarkan kurikulum yang telah mereka kembangkan.

\section{Metode}

Jenis Penelitian

Penelitian ini merupakan penelitian tindakan kelas (PTK) atau yang sering disebut classroom action research. Penelitian tindakan kelas mempunyai karakteristik khusus yakni sebuah penelitian yang dilakukan oleh dosen di kelasnya sendiri yang dibantu oleh peneliti dengan jalan merancang, melaksanakan, dan merefleksikan tindakan secara kolaboratif dengan tujuan untuk memperbaiki kinerja dosen, sehingga masalah belajar mahasiswa dapat teratasi dan prestasi dapat meningkat. Dalam pelaksanaannya PTK, didominasi kegiatan berpikir ulang (reflectif thinking).

Bentuk penelitian yang dipilih yaitu partisipasif. Partisipatif artinya bahwa orang yang akan melakukan tindakan juga harus terlibat dalam proses penelitian dari awal. Pelaku dalam penelitian ini adalah dosen pengampu mata kuliah materi pembelajaran IPS SD yang sekaligus sebagai peneliti. Peneliti menambah rekan observer agar observasi tindakan lebih mudah, lebih teliti, dan lebih obyektif. Rekan observer juga merupakan dosen pengampu mata kuliah materi pembelajaran IPS SD di kelas lain yang tidak dikenai tindakan.

\section{Waktu dan Tempat Penelitian}

Penelitian dilakukan di Prodi PGSD UAD kelas D semester 4 tahun ajaran 2013/ 2014. Penelitian dilaksanakan dalam 2 siklus. Siklus I dimulai pada tanggal 31 Mei 2014 dan Siklus II dimulai tanggal 10 Juni 2014.

Subjek Penelitian 
Jurnal Prima Edukasia, 4 (2), Juli 2016 - 152

Laila Fatmawati

Subjek dalam penelitian ini adalah mahasiswa PGSD UAD kelas D semester 4 tahun ajaran 2013/2014 yang berjumlah 46 mahasiswa. Untuk menentukan subjek penelitian ini digunakan teknik purposive sampling.

Teknik dan Instrumen Pengumpulan Data

Teknik pengumpulan data dalam penelitian ini adalah teknik tes dan non tes. Untuk teknik non tes antara lain: pertama, pengamatan/ observasi yang dilakukan oleh peneliti berupa pengamatan aktif, di mana peneliti melakukan pembelajaran secara langsung pada mahasiswa PGSD. Pengamatan difokuskan pada keaktifan dan pemahaman konsep IPS mahasiswa PGSD kelas D. Untuk mengukur keaktifan dan pemahaman konsep mahasiswa digunakan instrumen lembar observasi keaktifan yang terlebih dahulu dikonsultasikan dengan pihak ahli (expert judgement) untuk mengetahui kesesuaian lembar observasi dengan indikator yang dijadikan pedoman. Instrumen yang digunakan ada dua yaitu lembar observasi keaktifan dan lembar observasi pemahaman konsep. Hasil observasi keaktifan dan pemahaman konsep siklus I diuji validitas dan reliabilitasnya dengan bantuan SPSS.

Kedua, wawancara. Melalui wawancara, peneliti dapat mengetahui tanggapan/pendapat mahasiswa mengenai pembelajaran dengan menggunakan model learning cycle. Wawancara dilakukan setelah tindakan selesai yaitu setelah siklus II. Wawancara juga digunakan peneliti untuk mengumpulkan data pra penelitian. Instrumen yang digunakan adalah pedoman wawancara.

Ketiga, dokumentasi. Data yang diperoleh dari studi dokumentasi berupa foto-foto yang memberikan gambaran secara konkret mengenai aktivitas mahasiswa selama mengikuti proses pembelajaran, serta data berupa dokumen-dokumen lain. Dokumen-dokumen tersebut misalnya data nilai mahasiswa pada angkatan sebelumnya yang telah mengikuti perkuliahan materi pembelajaran IPS.

Keempat, catatan lapangan, selama pelaksanaan treatment berlangsung dilakukan pencatatan untuk mengetahui kelebihan dan kekurangan yang ada selama menggukan model learning cycle, serta mencatat hal-hal penting yang dapat menunjang penelitian.

Teknik tes berupa tes hasil belajar. Tes hasil belajar digunakan untuk mendapatkan data mengenai peningkatan pemahaman konsep selama mahasiswa menggunakan model learning cycle. Tes terdiri atas pretest, posttest siklus I dan posttest siklus II.

Instrumen yang digunakan berupa soal tes dibuat oleh peneliti yang terlebih dahulu dikonsultasikan dengan rekan observer dan dosen pembimbing penelitian, hal ini dilakukan untuk mengukur tingkat kesukaran soal yang disesuaikan dengan kemampuan mahasiswa serta untuk kualitas soal yang akan diujikan. Kemudian dilakukan uji instrumen tes hasil belajar untuk menentukan validitas dan reliabilitas soal. Hanya soal yang valid dan reliabel saja yang dibagikan pada mahasiswa.

Prosedur Penelitian

Penelitian tindakan kelas dilakukan melalui dua siklus yang tiap-tiap siklus terdiri atas empat langkah yaitu plan (perencanaan), action (tindakan), observation (observasi), dan refection (Arikunto, Suhardjono, \&Supardi, 2007, p.16). Sebelum memasuki tahap plan, didahului dengan kegiatan pra penelitian serta mengidentifikasi dan merumuskan masalah. Kegiatan pra penelitian ini meliputi mengumpulkan data awal untuk mengetahui nilai hasil UTS dan UAS pada mahasiswa PGSD. Dalam kegiatan pra penelitian dilakukan wawancara terhadap dosen tim dosen IPS untuk mengetahui permasalahan-permasalahan yang timbul saat perkuliahan sehingga menyebabkan hasil belajar mahasiswa masih banyak yang rendah. Tahap selanjutnya yaitu mengidentifikasi dan merumuskan masalah. Setelah melakukan langkah-langkah identifikasi masalah, diketahui bahwa permasalahan yang mendasar selama perkuliahan materi pembelajaran IPS SD masih rendahnya keaktifan dan pemahaman konsep IPS mahasiswa.

Tahap plan (perencanaan), diawali dengan merancang tindakan yang akan dilakukan antara lain: menyusun alur pembelajaran dengan model learning cycle 5E, menyiapkan rencana pembelajaran dan media pembelajaran yang sesuai dengan model pembelajaran learning cycle. Rencana pembelajaran yang akan digunakan terlebih dahulu dikonsultasikan dengan dosen pembimbing penelitian dan rekan observer, menyusun instrumen penelitian. Tahap action dilakukan dalam 5 tahap yaitu engagement, exploration, explanation, elaboration, evaluation.

Tahap observasi merupakan upaya mengamati keaktifan dan pemahaman konsep IPS pada mahasiswa PGSD kelas D selama pelaksanaan tindakan. Proses pengamatan juga meng- 
amati aktivitas dan perilaku mahasiswa pada saat pembelajaran di kelas. Observasi dilakukan selama proses pembelajaran berlangsung dengan menggunakan lembar observasi yang telah dibuat. Proses tindakan, pengaruh tindakan yang disengaja maupun tidak disengaja, situasi tempat tindakan, dan kendala-kendala tindakan semua dicatat dalam lembar catatan lapangan yang terencana dan fleksibel.

Tahap terakhir yaitu refleksi. Refleksi bertujuan untuk mengetahui kekurangankekurangan maupun kelebihan-kelebihan yang terjadi selama pembelajaran. Refleksi dilakukan oleh peneliti dan rekan observer dengan cara berdiskusi. Refleksi merupakan bagian yang sangat penting dalam penelitian tindakan kelas dan merupakan langkah terakhir yang dilakukan dalam sebuah siklus. Kegiatan refleksi akan memantapkan perencanaan dan tindakan yang akan dilakukan pada siklus berikutnya. Jika siklus I telah selesai dilaksanakan maka pelaksanaan siklus II akan diawali lagi dengan sebuah perencanaan, dan dilanjutkan dengan tindakan, observasi, dan refleksi yang memperhatikan saran-saran dan masukan yang diperoleh dari refleksi pada siklus I.

Teknik Analisis Data

Langkah-langkah analisis data dalam penelitian ini adalah analisis kualitatif dan kuantitatif. Analisis kuantitatif digunakan untuk mengolah hasil perolehan data berupa angka berbantuan SPSS 19.00. Analisis data kualitatif menggunakan model Miles dan Hubberman dengan tahapan (1) reduksi data meliputi penyeleksian data melalui ringkasan atau uraian singkat, dan pengelolaan data ke dalam pola yang lebih terarah. Data-data hasil observasi, dokumentasi, dan wawancara dikelompokkan berdasarkan kepentingan pada rumusan masalah. (2) Penyajian data (data display) yang dilakukan proses penampilan data secara lebih sederhana dalam bentuk paparan naratif, grafik dan referensi tabular. (3) Penarikan kesimpulan (verification), data yang terkumpul tersebut disajikan dalam bentuk pernyataan kalimat atau formula yang singkat dan padat tetapi mengandung pengertian yang luas.

Validitas dan Reliabilitas Intrumen

Instrumen-instrumen yang digunakan dalam penelitian harus memenuhi beberapa persyaratan. Persyaratan pokok dari lembar observasi dan instrument tes yang digunakan untuk mengumpulkan data penelitian yaitu validitas dan reliabilitas instrumen. Validitas dilakukan dengan dua cara yaitu validitas rasional/logis dan validitas empiris. Validitas rasional/logis dalam penelitian ini menggunakan validitas isi (content validity) dan validitas konstruk (construct validity). Penentuan validitas rasional/ logis dilakukan dengan meminta pertimbangan ahli (expert judgement). Instrumen yang divalidasi meliputi: (1) sintaks model pembelajaran learning cycle 5E, tujuan dari validasi model pembelajaran adalah untuk menentukan layak atau tidaknya model tersebut digunakan dalam penelitian. (2) Lembar observasi, tujuan dari validasi ini adalah untuk menentukan apakah instrumen lembar observasi sudah mencakup semua indikator yang dijadikan pedoman mengukur tingkat keaktifan dan pemahaman konsep. (3) Soal tes hasil belajar, pakar dilibatkan dalam validitas instrumen hasil belajar adalah dosen pembimbing dan rekan dosen IPS. Validitas instrumen tes yang digunakan dalam penelitian ini meliputi validitas isi hasil belajar IPS merupakan validitas yang berkenaan dengan ketepatan isi tes yang disusun sesuai konsep IPS atau kompetensi dasar, dan validitas konstruk tes hasil belajar IPS merupakan validitas tes yang berkenaan kesesuaian butir-butir tes dengan indikator pada kisi-kisi.

Validitas empirik diperoleh dari uji coba instrumen. Instrumen yang dianalisis secara empiris terdiri atas tes hasil belajar IPS, lembar observasi keaktifan, dan lembar observasi pemahaman konsep.

Uji coba lapangan untuk tes hasil belajar dilaksanakan tanggal 17 Mei 2014. Soal tes diujicobakan pada mahasiswa semester VI kelas A sebanyak 33 mahasiswa. Soal yang diujicobakan sejumlah 20 butir berupa soal uraian. Dari hasil uji coba diperoleh kesimpulan ada tidak ada soal yang gugur. Semua soal yang diujicobakan memiliki nilai $r$ krisis > 0,30 sehingga dinyatakan valid. Instrumen lembar observasi yang diukur tingkat validitasnya diambil dari hasil observasi keaktifan dan pemahaman konsep siklus I. Dari hasil perhitungan validitas dinyatakan bahwa semua hasil yang ada dalam lembar observasi dinyatakan valid, karena memiliki nilai $r$ hitung $>0,30$ (Sugiyono, 2007).

Instrumen yang diukur reliabilitasnya yaitu soal tes hasil belajar, lembar observasi keaktifan dan pemahaman konsep. Reliabilitas tes hasil belajar IPS diperoleh dengan melakukan uji coba tes hasil belajar di lapangan pada mahasiswa semester VI kelas A sebanyak 33 mahasiswa. Reliabilitas tes hasil belajar IPS 
bentuk uraian dianalisis dengan rumus alpha cronbach menggunakan program SPSS 19.00 for windows. Dikatakan reliabel jika nilai alpha > 0,6 (Ghozali, 2009:46).

Dari hasil uji coba diperoleh kesimpulan ada tidak ada soal yang gugur. Semua soal yang diujicobakan memiliki nilai nilai alpha > 0,6 sehingga dinyatakan reliabel. Dari hasil olah data, instrumen tes hasil belajar dikatakan reliabel karena memiliki nilai alpha 0.923 . Dari hasil olah data uji coba, instrumen lembar observasi keaktifan dan pemahaman konsep dikatakan reliabel karena memiliki nilai alpha 0,772 .

\section{Kriteria Keberhasilan Tindakan}

Indikator keberhasilan dalam penelitian ini adalah meningkatnya keaktifan dan pemahaman konsep IPS mahasiswa yang dapat dilihat selama kegiatan proses pembelajaran berlangsung serta meningkatnya hasil belajar IPS. Indikator yang dapat menjadi pedoman dalam pengukuran keaktifan bila memiliki kriteria berikut ini.

Tabel 1. Indikator Keaktifan

\begin{tabular}{cll}
\hline No & $\begin{array}{l}\text { Indikator } \\
\text { Keaktifan }\end{array}$ & \multicolumn{1}{c}{ Deskripsi } \\
\hline 1 & $\begin{array}{l}\text { Visual } \\
\text { activities }\end{array}$ & $\begin{array}{l}\text { Membaca petunjuk pada lembar akti- } \\
\text { fitas mahasiswa, memperhatikan } \\
\text { penjelasan dan tayangan dengan } \\
\text { baik. }\end{array}$ \\
\hline 2 & $\begin{array}{l}\text { Oral } \\
\text { activities }\end{array}$ & $\begin{array}{l}\text { Aktif bertanya, mengeluarkan penda- } \\
\text { pat, memberi saran dan berdiskusi. }\end{array}$ \\
\hline 3 & $\begin{array}{l}\text { Listening } \\
\text { activities }\end{array}$ & $\begin{array}{l}\text { Mendengarkan uraian materi, hasil } \\
\text { diskusi, dan tanyangan dengan } \\
\text { seksama. }\end{array}$ \\
\hline 4 & $\begin{array}{l}\text { Writing } \\
\text { activities }\end{array}$ & $\begin{array}{l}\text { Mencatat materi-materi penting saat } \\
\text { presentasi, diskusi, dan penjelasan } \\
\text { dari dosen. }\end{array}$ \\
\hline 5 & $\begin{array}{l}\text { Mental } \\
\text { activities }\end{array}$ & $\begin{array}{l}\text { Memberi tanggapan, menganalisis } \\
\text { dan memberi solusi pemecahan } \\
\text { masalah. }\end{array}$ \\
\hline 6 & $\begin{array}{l}\text { Emotional } \\
\text { activities }\end{array}$ & $\begin{array}{l}\text { Mengikuti proses perkuliahan dengan } \\
\text { antusias, bersemangat, dan gigih } \\
\text { mempelajari materi yang sulit. }\end{array}$ \\
\hline Sumber: Sardiman
\end{tabular}

Sumber: Sardiman (2014)

Indikator pemahaman konsep antara lain:

Tabel 2. Indikator Pemahaman Konsep

\begin{tabular}{cl}
\hline No. & \multicolumn{1}{c}{ Indikator Pemahaman Konsep } \\
\hline 1 & Kemampuan menjelaskan konsep \\
\hline 2 & $\begin{array}{l}\text { Kemampuan menggunakan konsep pada situasi } \\
\text { yang berbeda }\end{array}$ \\
\hline 3 & $\begin{array}{l}\text { Kemampuan mengembangkan beberapa akibat dari } \\
\text { adanya suatu konsep }\end{array}$ \\
\hline 4 & Kemampuan mengkomunikasikan konsep \\
\hline 5 & $\begin{array}{l}\text { Kemampuan menghargai, menanggapi dan } \\
\text { memberikan tanggapan }\end{array}$ \\
\hline
\end{tabular}

Untuk menghitung indikator keaktifan dan pemahaman konsep digunakan lembar observasi. Hasil analisis data observasi kemudian disajikan secara deskriptif.

Aspek hasil belajar, dihitung menggunakan nilai tes hasil belajar, dengan kriteria keberhasilan hasil belajar sebagai berikut:

Tabel 3. Persentase Kriteria Keberhasilan Hasil Belajar

\begin{tabular}{ccc}
\hline Aspek yang dinilai & $\begin{array}{c}\text { Target } \\
\text { Siklus I }\end{array}$ & $\begin{array}{c}\text { Target } \\
\text { Siklus II }\end{array}$ \\
\hline Hasil belajar & $75 \%$ & $100 \%$ \\
(aspek kognitif) & Tuntas & Tuntas \\
\hline
\end{tabular}

\section{Hasil dan Pembahasan}

\section{Hasil Pra Penelitian}

Sebelum melaksanakan penelitian, peneliti melakukan pengumpulan data awal melalui studi dokumentasi dan wawancara. Dokumentasi ditujukan untuk mengetahui nilai UTS dan nilai UAS IPS mahasiswa PGSD. Dari hasil penelusuran dokumen tersebut diperoleh data dari 110 orang mahasiswa, 17 di antaranya mendapat nilai dibawah KKM (65) untuk Ujian Tengah Semester, dan 59 orang mahasiswa yang mendapat nilai di bawah KKM (65) untuk Ujian Akhir Semester. Bila dihitung dalam persen, maka ada $15,45 \%$ mahasiswa yang mendapat nilai di bawah KKM untuk Ujian Tengah Semester dan 53,6\% mahasiswa yang mendapat nilai dibawah KKM untuk Ujian Akhir Semester. Dari hasil UTS dan UAS ini disimpulkan bahwa pemahaman konsep IPS mahasiswa masih rendah.

Untuk mendukung data awal penelitian juga dilakukan wawancara dengan tim dosen pengampu mata kuliah IPS tentang mengetahui permasalahan-permasalahan yang timbul saat perkuliahan sehingga menyebabkan hasil belajar mahasiswa masih banyak yang rendah. Dari hasil wawancara diperoleh kesimpulan bahwa yang menjadi permasalahan mahasiswa bahwa selama proses perkuliahan, keaktifan mahasiswa dalam mengikuti diskusi kelompok sangat rendah. Mereka kurang antusias memperhatikan materi-materi IPS yang disajikan temannya ketika presentasi kelompok.

Masalah-masalah tersebut tentunya akan menghambat proses pembelajaran yang terhadap belum optimalnya hasil belajar. Untuk mengatasi masalah tersebut, peneliti berusaha mencari pemecahan masalah. Peneliti mencoba menggunakan model yang dapat merangsang keaktifan mahasiswa untuk belajar sekaligus 


\section{Jurnal Prima Edukasia, 4 (2), Juli 2016 - 155}

Laila Fatmawati

mampu meningkatkan pemahaman konsep mahasiswa. Setelah melakukan telusur literatur, solusi yang dipilih yaitu menggunakan model pembelajaran learning cycle.

\section{Deskripsi Data Hasil Penelitian Siklus I}

\section{Rencana}

Siklus I diawali dari perencanaan penelitian, dengan mempersiapkan instrumen rencana pembelajaran yang dirancang untuk tiga kali pertemuan. Di dalam rencana pembelajaran, dirancang materi atau pokok bahasan yang akan dibahas yaitu materi kenampakan alam, pembagian kelompok dengan memperhatikan heterogenitas mahasiswa, menyusun lembar kerja mahasiswa, menyusun instrumen penelitian, dan menyiapkan peralatan yang diperlukan untuk pengumpulan data dan alat dokumentasi.

\section{Pelaksanaan}

Siklus I terdiri atas tiga pertemuan. Pertemuan pertama pada siklus I dilaksanakan pada hari Sabtu, 31 Mei 2014. Kegiatan yang diawali dengan pretest untuk mengukur pemahaman konsep awal mahasiswa. Sebelum pretest dilaksanakan, terlebih dahulu diawali dengan berdoa. Pretest yang dimulai sekitar pukul 07.30 WIB dan berakhir pukul 09.00 WIB. Selama pretest berlangsung tidak ada kendala, semua berjalan dengan lancar. Ada satu orang mahasiswa yang tidak hadir sehingga harus menyusul pretest pada hari Senin, 2 Juni 2014.

Setelah pretest selesai, kemudian dilanjutkan dengan tindakan model pembelajaran learning cycle dengan tahap engagement. Tahap engagement ini dimulai dengan dosen bertanya secara lisan mengenai kondisi kenampakan alam yang ada di Indonesia. Dari proses tanya jawab ini timbul minat mahasiswa terhadap topik kenampakan alam di Indonesia yang akan dipelajari mereka, sekaligus untuk mengukur pengetahuan awal mahasiswa tentang materi kenampakan alam. Dosen memotivasi mahasiswa untuk berani memberikan contoh-contoh permasalahan dalam kehidupan sehari-hari yang berkaitan dengan materi yang dipelajari, serta menganalisis miskonsepsi yang selama ini dipahami mahasiswa.

Hanya beberapa mahasiswa yang aktif menjawab dan memberi tanggapan tentang pertanyaan yang diajukan oleh dosen. Tapi masih ada banyak mahasiswa yang tidak memperhatikan dan ikut aktif dalam tahap engagement ini. Tahap engagement berlangsung sekitar 15 menit, sehingga belum maksimal dalam menumbuhkan minat mahasiswa terhadap materi yang akan dibahas.

Setelah tahap engagement, dosen membagi mahasiswa menjadi 9 kelompok-kelompok kecil yang membahas sub-sub materi terkait kenampakan alam di wilayah Indonesia dan permasalahannya. Tahap diskusi kelompok ini yang disebut dengan tahap exploration. Exploration bertujuan untuk menggali pengetahuan mahasiswa melalui pembagian kelompok kecil dengan mempertimbangkan heterogenitas mahasiswa.

Dosen mengumumkan agar setiap kelompok mengerjakan lembar kerja yang diberikan. Masing-masing kelompok berdiskusi untuk menyelesaikan topik yang ditugaskan oleh dosen serta membuat power point. Untuk tahap exploration diselesaikan kurang lebih 90 menit. Karena keterbatasan waktu dan tempat, perkuliahan tahap exploration dilanjutkan di ruang diskusi. Perkuliahan yang dilakukan di ruang diskusi ini mendapat hambatan, ruangan yang sempit menyebabkan mahasiswa tidak leluasa dalam melakukan kerja kelompok. Posisi duduk antar kelompok yang saling berdekatan sehingga memungkinkan kelompok satu menggangu kelompok lainnya. Masih banyak mahasiswa yang tidak ikut aktif dalam proses diskusi kelompok serta membuat power point.

Pertemuan kedua pada siklus I dilaksanakan ada hari Sabtu, 7 Juni 2014. Perkulihan dimulai pukul 08.00 WIB dan dilaksanakan di laboratorium pembelajaran kelas awal yang memiliki ruangan cukup besar. Pertemuan kedua ini, memasuki tahap explanation. Tahap explanation ini masing-masing kelompok mempresentasikan hasil diskusinya di depan kelas, kelompok audience memperhatikan sekaligus memberikan pertanya, sanggahan, serta masukan.

Proses diskusi kelompok diawali dengan presentasi kelompok II, kemudian dilanjutkan kelompok I. Di awal presentasi, minat mahasiswa untuk bertanya masih kurang, banyak mahasiswa yang malu-malu untuk bertanya ataupun memberikan sanggahan. Namun setelah masuk pada kelompok 3, ada beberapa mahasiswa mulai berani untuk mengajukan beberapa pertanyan maupun sanggahan. Namun, belum semua perwakilan kelompok yang ikut aktif dalam proses diskusi.

Selama sesi presentasi dan tanya jawab, dosen memberikan beberapa pertanyaan terkait materi yang dibahas dengan menempatkan pada 
situasi yang berbeda. Tahap ini merupakan tahap elaboration, yang bertujuan untuk menggali kemampuan analisis mahasiswa sehingga pemahaman konsep mahasiswa pun ikut berkembang. Mahasiswa saling berdiskusi dengan kelompoknya untuk mencoba menjawab pertanyaan yang diberikan oleh dosen. Namun hanya beberapa kelompok saja yang dapat menjawab pertanyaan yang diberikan dosen, sedangkan kelompok lain masih pasif. Setelah semua kelompok selesai presentasi, kemudian dosen memberikan penguatan atas konsep yang sedang dipelajari, meluruskan persepsi yang keliru selama proses diskusi.

Pertemuan ke tiga dilaksanakan pada hari Senin, 9 Juni 2014. Pelaksanaan tindakan pada pertemuan ketiga ini merupakan tahap evaluation yaitu mahasiswa menyelesaikan soal tes hasil belajar untuk mengukur tingkat pemahaman konsep mahasiswa secara individu setelah tindakan diberikan.

Pada tahap evaluation dilakukan post tes I untuk mengukur tingkat pemahaman konsep IPS pada mahasiswa setelah memperoleh pengetahuan dari proses diskusi. Mahasiswa secara individu harus meyelesaikan tes hasil belajar dan tidak diperkenankan saling bertanya. Tahap evaluation ini dilaksanakan pukul 13.00-14.30 WIB. Tahap evaluation berjalan lancar dan tertib.

\section{Observasi}

Berdasarkan hasil tindakan pada siklus I diperoleh hasil tentang keaktifan, pemahaman konsep, dan hasil belajar pada saat pretest serta posttest. Penjabaran hasil olah data sebagai berikut:

\section{Keaktifan Belajar Mahasiswa}

Lembar observasi digunakan sebagai instrumen untuk mengetahui tingkat keaktifan dan pemahaman konsep mahasiswa, selanjutnya data yang diperoleh dihitung dan dicari persentasenya. Data berupa persentase tersebut selanjutnya dikualifikasikan berdasarkan kriteria yang telah ditetapkan.

Dari hasil olah data observasi keaktifan mahasiswa yang diberikan setelah siklus I berakhir kepada 46 mahasiswa, diperoleh sebanyak 8 mahasiswa memiliki keaktifan dengan kriteria baik, 30 mahasiswa memiliki keaktifan dengan kriteria cukup, dan 8 mahasiswa memiliki memiliki keaktifan dengan kriteria kurang. Bila diukur dengan persentase maka 17,4\% mahasiswa memiliki keaktifan dengan kriteria baik,
65,2\% mahasiswa memiliki keaktifan dengan kriteria cukup, dan 17,4\% mahasiswa memiliki memiliki keaktifan dengan kriteria kurang. Berikut disajikan diagram batang keaktifan mahasiswa pada akhir siklus I:

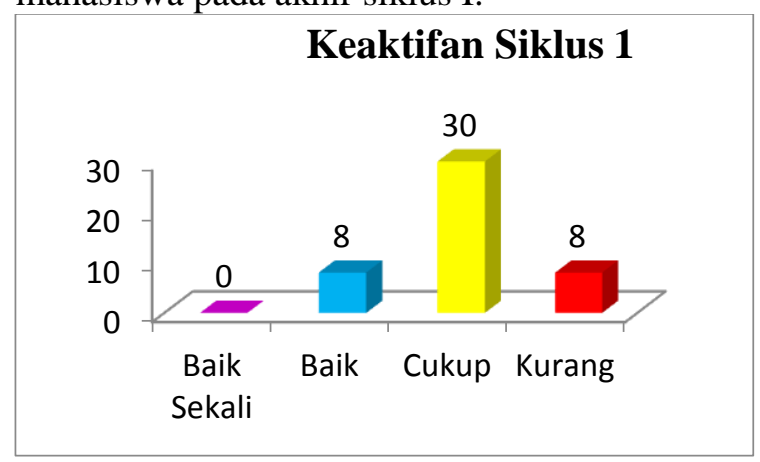

Diagram 1. Keaktifan mahasiswa PGSD
kelas D pada siklus I

\section{Pemahaman Konsep}

Dari hasil olah data observasi pemahaman konsep mahasiswa yang diberikan setelah siklus I berakhir kepada 46 mahasiswa, diperoleh sebanyak 5 mahasiswa memiliki pemahaman konsep dengan kriteria baik, 37 mahasiswa memiliki pemahaman konsep dengan kriteria cukup, dan 4 mahasiswa memiliki pemahaman konsep dengan kriteria kurang. Bila diukur dengan persentase maka 10,9\% mahasiswa memiliki pemahaman konsep dengan kriteria baik $80,4 \%$ mahasiswa memiliki pemahaman konsep dengan kriteria cukup, dan 8,7 \% mahasiswa memiliki pemahaman konsep dengan kriteria kurang. Berikut disajikan diagram batang pemahaman konsep pada akhir siklus I:

\section{Pemahaman Konsep Siklus 1}

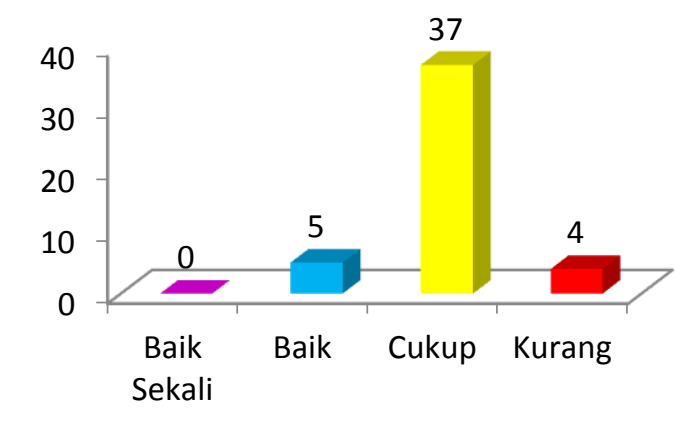

Diagram 2. Pemahaman Konsep Mahasiswa PGSD Kelas D pada siklus I

\section{Hasil Belajar Mahasiswa}

Dari hasil olah data untuk instrumen uji kemampuan belajar mahasiswa yang diberikan saat pretest kepada 46 mahasiswa, diperoleh 
sebanyak 1 mahasiswa tuntas dalam belajar, dan 45 mahasiswa tidak tuntas. Batas ketuntasan diukur dari nilai yang diperoleh minimal 65. Bila diukur dengan persentase maka 2,2 \% mahasiswa tuntas dalam belajar, dan $97,8 \%$ mahasiswa tidak tuntas dalam belajar. Berikut disajikan diagram batang hasil belajar mahasiswa pada saat pretest:

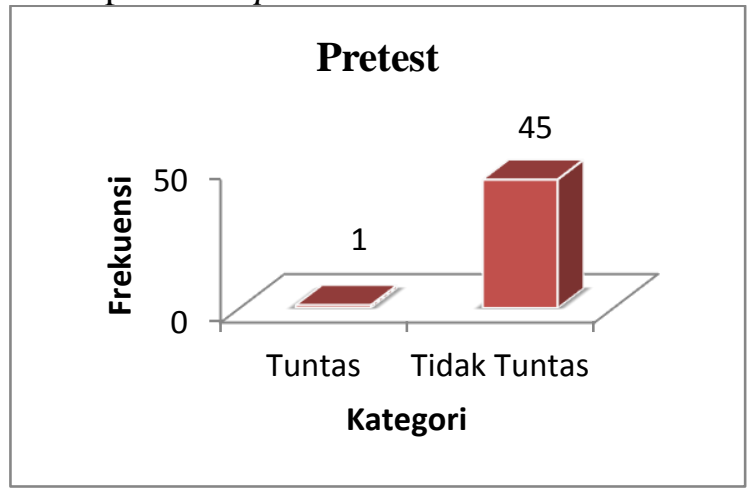

Diagram 3. Hasil Belajar Mahasiswa PGSD

Kelas D pada pretest (Sebelum Tindakan)

Dari hasil olah data tes hasil belajar mahasiswa yang diberikan setelah siklus I berakhir kepada 46 mahasiswa, diperoleh sebanyak 19 mahasiswa tuntas dalam belajar, dan 27 mahasiswa tidak tuntas dalam belajar. Bila diukur dengan persentase maka 41,3\% mahasiswa tuntas dalam belajar, 58,7 \% mahasiswa tidak tuntas dalam belajar. Berikut disajikan diagram batang tes hasil belajar siswa siswa pada akhir siklus I.

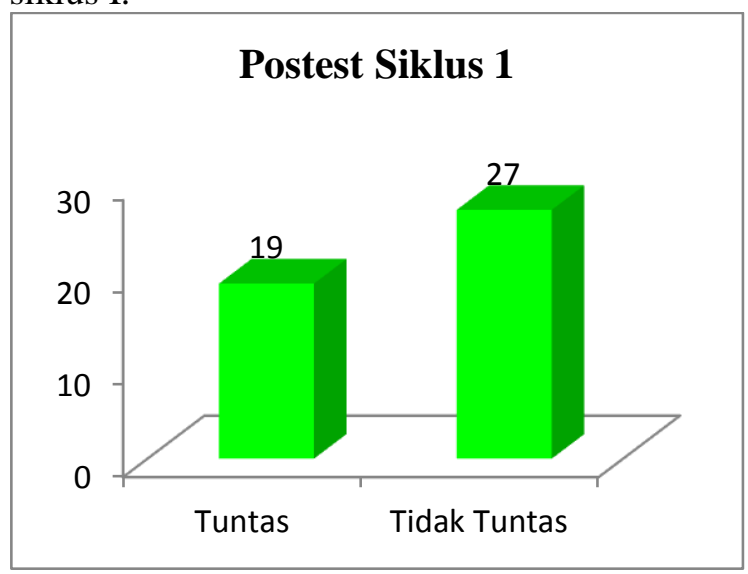

Diagram 4. Hasil Belajar Mahasiswa PGSD Kelas D pada Posttest Siklus I

Setelah siklus I selesai kemudian dilakukan refleksi dan tindak lanjut untuk mengetahui kekurangan yang terdapat di siklus I sehingga dapat dilakukan perbaikan di siklus selanjutnya.
Refleksi

Refleksi pada siklus I dilakukan dengan mengkaji hasil tindakan serta permasalahan yang dihadapi selama tindakan pada siklus I berlangsung. Ada beberapa kelemahan yang ditemukan dalam siklus I, antara lain: (1) Lembar kerja yang dibagikan kepada mahasiswa kurang mampu meningkatkan keaktifan mahasiswa, sehingga berdampak mahasiswa kurang antusias dalam menyelesaikan lembar kerja tersebut. (2) keterbatasan ruang kelas, sehingga posisi tempat duduk antar kelompok yang terlalu dekat sehingga memungkinkan mahasiswa untuk saling mengganggu anggota kelompok lain. (3) Belum ada kesadaran dari dalam diri mahasiswa untuk berani bertanya dan mengemukakan pendapat. (4) Dosen kurang mampu membangkitkan minat mahasiswa terkait materi kenampakan alam pada tahap angagement.

Berdasarkan hasil analisis dan refleksi siklus I, langkah selanjutnya pada siklus II kelemahan harus bisa diminimalisis dan rancangan tindakan harus dapat meningkatkan keaktifan dan pemahaman konsep mahasiswa.

Untuk meningkatkan keaktifan konsep dan pemahaman konsep mahasiswa, peneliti melakukan diskusi dengan dosen pengampu mata kuliah materi pembelajaran IPS kelas lain untuk merancang tindak lanjut yang dapat meminimalisir kelemahan pada siklus I. Dari hasil diskusi tersebut diperoleh pemecahan kelemahan sebagai berikut: (1) Lembar kerja mahasiswa tidak dalam bentuk soal secara tertulis di kertas, tetapi dalam bentuk analisis video. (2) Mengatur posisi kelompok agar tidak terlalu berdekatan untuk memilimalisir gangguan antar kelompok dan agar mobilitas peneliti saat observasi menjadi lebih leluasa. (3) Mema$\mathrm{cu}$ mahasiswa agar lebih berani mengajukan pertanyaan dan mengemukakan pendapat, dengan memberikan reward point bagi siswa yang berani bertanya atau memberikan pendapat. (4) Dosen membuat gerakan ice breaking untuk menyegarkan pikiran dan tubuh mahasiswa sehingga mahsiswa secara fisik dan psikis siap untuk melaksanakan perkuliahan, menyiapkan video yang digunakan dalam tahap angagement. (5) Dosen meminta masing-masing kelompok agar menyiapkan 1 buat laptop untuk pertemuan berikutnya. 
Jurnal Prima Edukasia, 4 (2), Juli 2016 - 158

Laila Fatmawati

Deskripsi Data Hasil Penelitian Siklus II

\section{Perencanaan}

Perencanaan tindakan siklusi II dilakukan dengan mempersiapkan materi lanjutan dari siklus I yaitu tentang materi gelaja alam. Menyusun rencana pembelajaran untuk tiga kali pertemuan, membuat lembar kerja mahasiswa yang berbentuk video bukan dalam bentuk soal tertulis, membuat gerakan ice breaking, membuat instrument penelitian dan menyiapkan peralatan dokumentasi.

\section{Pelaksanaan}

Pertemuan pertama pada siklus II dilaksanakan pada hari Selasa, 10 Juni 2014. Pertemuan pertama ini dimulai dosen memberikan salam dan memimpin berdoa, kemudian kegiatan siklus II dosen menyampaikan topik yang akan dibahas adalah tentang gejala alam. Sebelum memasuki tahap angagement, dosen meminta seluruh mahasiswa berdiri kemudian dipimpin oleh dosen melakukan ice breaking untuk menyegarkan pikiran dan tubuh sehingga mahasiswa siap mengikuti proses perkuliahan. Kegiatan ice breaking ini cukup membantu menumbuhkan semangat dan mengembalikan keceriaan mahasiswa.

Memasuki tahap engagement, dosen menanyangkan video gejala alam yang pernah melanda Indonesia, dari video tersebut kemudian dosen memberikan pertanyaan kepada mahasiswa tentang peristiwa gejala alam yang pernah dialami oleh mahasiswa. pertanyaan.

Dalam siklus II ini sudah banyak mahasiswa yang aktif dalam tahap engagement. Banyak mahasiswa yang menceritakan pengalaman mereka yang pernah mengalami atau menyaksikan peristiwa gejala alam secara langsung.

Setelah tahap engagement kemudian pembelajaran masuk ke tahap exploration. Mahasiswa kelas D yang terdiri atas 46 mahasiswa dibagi ke dalam 9 kelompok dengan memperhatikan heterogenitas secara jenis kelamin, tempat tinggal, dan kecerdasan kognitif. Masing-masing kelompok diberi soal dan lembar kerja mahasiswa berupa video gejala alam untuk didiskusikan dengan anggota kelompoknya.

Masing-masing kelompok berdiskusi untuk menyelesaikan topik serta membuat resume untuk dipresentasikan pada pertemuan selanjutnya. Pada tahap ini semua mahasiswa berkonsentrasi mengamati video kemudian membuat resume. Pada siklus II ini semua mahasiswa terlihat aktif untuk menyelesaikan tugas yang diberikan dosen, terlihat dengan jelas antusiasme mahasiswa ketika mengamati video gejala alam. Mayoritas mahasiswa memiliki gaya belajar visual sehingga sangat antusias ketika menggunakan pembelajaran yang memanfaatkan video. Resume dibuat dalam bentuk mind mapping.

Pertemuan kedua pada siklus II dilaksanakan ada hari Sabtu, 14 Juni 2014. Pertemuan kedua ini, memasuki tahap explanation, dengan tujuan mendorong mahasiswa untuk mampu mempresentasikan konsep yang diperoleh dari hasil diskusi.

Tahap explanation ini masing-masing kelompok mempresentasikan hasil diskusinya di depan kelas, hasil resume dibuat dalam bentuk mind mapping sehingga merangsang daya kreativitas mahasiswa untuk mendorong kemampuan menjelaskan dalam bentuk naratif secara lisan. Tampilan mind mapping menjadi salah satu aspek yang dinilai oleh dosen, sehingga setiap kelompok berusaha membuat mind mapping sebagus mungkin.

Proses diskusi kelompok diawali dengan presentasi kelompok I kemudian dilanjutkan urut kelompok berikutnya. Proses diskusi kelompok sudah mampu meningkatkan keaktifan mahasiswa untuk bertanya. Pada tahap ini sudah banyak mahasiswa yang berani memberikan pertanyaan, maupun pendapat. Seluruh kelompok sudah terlibat aktif dalam proses diskusi. Dosen sudah mulai mampu memberikan motivasi kepada mahasiswa untuk berani bertanya dan memberikan masukan atau penguatan jawaban.

Ketika sesi presentasi dan tanya jawab, dosen memancing pertanyaan terkait materi yang dibahas dengan menempatkan pada situasi yang berbeda, yaitu memberikan video tentang gejala alam di beberapa negara yang belum pernah dilihat oleh mahasiswa. Tahap ini merupakan tahap elaboration, yang bertujuan untuk menggali kemampuan analisis mahasiswa sehingga pemahaman konsep mahasiswa pun ikut berkembang. Mahasiswa saling berdiskusi dengan kelompoknya untuk mencoba menjawab pertanyaan yang diberikan oleh dosen. Setelah semua kelompok selesai presentasi, kemudian dosen memberikan penguatan atas konsep yang sedang dipelajari, meluruskan miskonsepsi yang ditemukan selama proses diskusi. Tahap elaboration berjalan dengan lancar, banyak mahasiswa yang mulai aktif menjawab pertanyaan 
yang diajukan oleh dosen. Setiap mahasiswa yang aktif diberikan reward 1 point. Mahasiswa berebut untuk mendapatkan point terbanyak.

Pertemuan ke tiga dilaksanakan pada hari Senin, 23 Juni 2014. Pelaksanaan tindakan pada pertemuan ketiga ini merupakan tahap evaluation yaitu mahasiswa menyelesaikan soal tes hasil belajar untuk mengukur tingkat pemahaman konsep mahasiswa secara individu setelah tindakan diberikan.

Tahap evaluation dilakukan posttes siklus II untuk mengukur tingkat pemahaman konsep IPS pada mahasiswa setelah memperoleh pengatahuan dari proses diskusi. Mahasiswa secara individu harus meyelesaikan tes hasil belajar dan tidak diperkenankan saling bertanya. Tahap evaluation berjalan lancar dan tertib.

\section{Observasi}

Berdasarkan hasil tindakan pada siklus II diperoleh hasil tentang keaktifan, pemahaman konsep, dan hasil belajar pada saat pretest serta posttest. Penjabaran hasil olah data sebagai berikut:

\section{Keaktifan Mahasiswa}

Dari hasil olah data observasi keaktifan mahasiswa yang diberikan setelah siklus II berakhir kepada 46 mahasiswa, diperoleh sebanyak 8 mahasiswa memiliki keaktifan dengan kriteria sangat baik, 38 mahasiswa memiliki keaktifan dengan kriteria baik. Bila diukur dengan persentase maka 17,4\% mahasiswa memiliki keaktifan dengan kriteria sangat baik, 82,6\% mahasiswa memiliki keaktifan dengan kriteria baik. Berikut disajikan diagram batang keaktifan mahasiswa pada akhir siklus II:

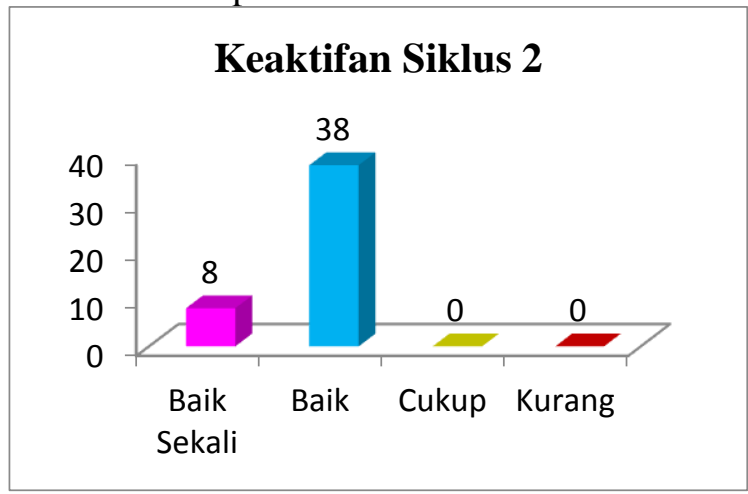

Diagram 5. Keaktifan Mahasiswa PGSD Kelas D pada Siklus II

\section{Pemahaman Konsep}

Dari hasil olah data observasi pemahaman konsep mahasiswa yang diberikan setelah siklus II berakhir kepada 46 mahasiswa, diperoleh sebanyak 12 mahasiswa memiliki pemahaman konsep dengan kriteria sangat baik, 34 mahasiswa memiliki pemahaman konsep dengan kriteria baik. Bila diukur dengan persentase maka $26,1 \%$ mahasiswa memiliki pemahaman konsep dengan kriteria sangat baik dan 73,9\% mahasiswa memiliki pemahaman konsep dengan kriteria baik. Berikut disajikan diagram batang pemahaman konsep pada akhir siklus II:

\section{Pemahaman Konsep Siklus 2}

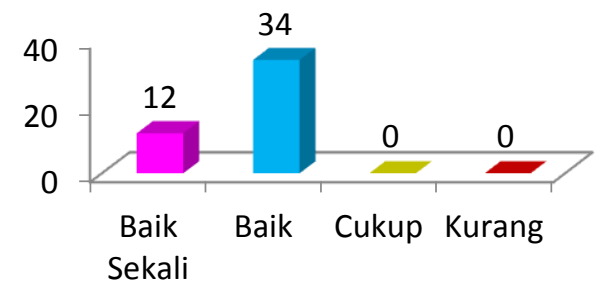

Diagram 6. Pemahaman Konsep Mahasiswa PGSD Kelas D pada Siklus II

\section{Hasil Belajar}

Dari hasil olah data untuk instrumen uji kemampuan belajar siswa yang diberikan saat posttest siklus II kepada 46 mahasiswa, diperoleh semua mahasiswa tuntas dalam belajar. Bila diukur dengan persentase maka $100 \%$ mahasiswa tuntas dalam belajar.

Berikut disajikan diagram batang hasil belajar mahasiswa pada saat posttest siklus II:

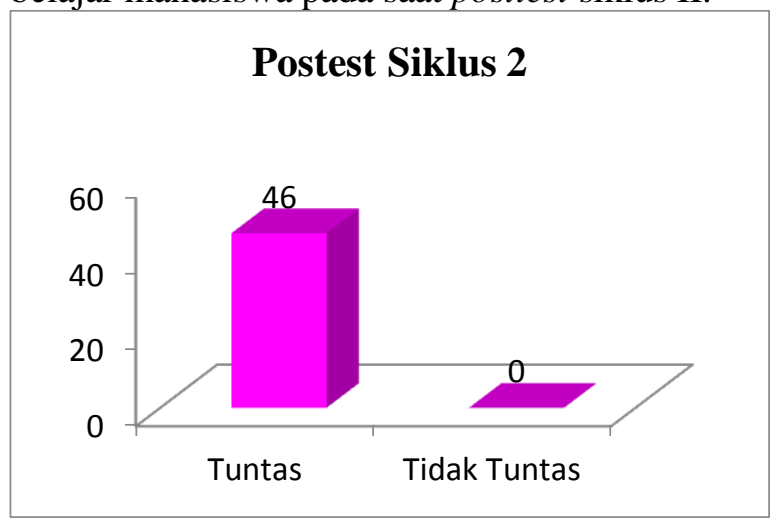

Diagram 7. Hasil Belajar Mahasiswa PGSD Kelas D pada Posttest Siklus II

Jika dibandingkan dengan hasil belajar saat pre tes dan siklus I maka hasil belajar siswa pada kuis siklus II dapat dikatakan mengalami peningkatan. Peningkatan ini dapat dilihat dari 


\section{Jurnal Prima Edukasia, 4 (2), Juli 2016 - 160}

Laila Fatmawati

persentase ketuntasan. Kenaikan ini dikarenakan, mahasiswa sudah lebih aktif dalam mengikuti proses pembelajaran, sehingga pemahaman konsep pun ikut meningkat.

\section{Refleksi}

Refleksi pada siklus II dilakukan dengan mengkaji hasil tindakan, observasi dan wawancara serta permasalahan yang dihadapi selama tindakan pada siklus II berlangsung. Hasil penelitian ini secara keseluruhan menunjukan adanya peningkatan keaktifan dan pemahaman konsep mahasiswa dalam proses pembelajaran dengan menggunakan model learning cycle. Hal ini dapat dilihat dari antusiasme mahasiswa dalam setiap tahapan yang ada dalam learning cycle. Kriteria keberhasilan tindakan siklus II telah terpenuhi sehingga tindakan diakhiri sampai siklus II saja dan tidak dilanjutkan ke siklus III.

\section{Pembahasan}

Dari hasil tindakan selama siklus I dan II terbukti bahwa penggunaan model learning cycle 5E mampu meningkatkan keaktifan dan pemahaman konsep IPS pada mahasiswa PGSD. Indikator keberhasilan dan kualitas suatu pembelajaran ditentukan dari keaktifan dan penguasaan konsep dari mahasiswa selama proses pembelajaran. Seperti pendapat Baharudin (2010) bahwa penentu kesuksekan dalam belajar adalah keaktifan dari masingmasing individu.

Model learning cycle merupakan model pembelajaran yang berbasis konstruktivisme dengan pola bersiklus. Langkah-langkah dalam learning cycle 5E merangsang mahasiswa untuk aktif membangun pemahaman konsep mereka sendiri. Tahap exploration merupakan tahap dimana mahasiswa diberi tugas pengamatan, dan menyimpulkan sendiri hasil pengamatannya. Dari kegiatan ini mahasiswa dilatih meningkatkan keterampilan berpikir tingkat tinggi, sehingga mampu merekonstruksi sendiri pemahaman konsep dari hasil pengamatan yang telah dilakukan.

Mahasiswa juga dilatih kemampuan berbicara dan mengeluarkan pendapat, bertanya, menyanggah pendapat dengan sopan di forum diskusi pada tahap explanation. Dosen hanya berperan sebagai fasilitator yang memotivasi mahasiswa untuk mengeluarkan ide-idenya, moderator untuk menengahi apabila diskusi sudah mulai tidak terkendali dan klarifikator apabila ada perdebatan pendapat yang tidak dapat diselaikan dengan baik. Tugas dosen bukan lagi sebagai satu-satunya pemberi informasi kepada mahasiswa. Menurut Wahyuni, Syamsu, \& Muslimin (2013) dalam pembelajaran learning cycle, seorang pengajar penekanan utamanya adalah berusaha mendorong siswanya untuk mengungkapkan ide-ide mereka dan membangun konsepnya selama proses pembelajaran, sehingga pembelajaran bersifat student center.

Tahap elaboration, mahasiswa akan dihadapkan pada kasus berbeda yang sering terjadi di kehidupan sehari-hari. Berdasarkan hasil penelitian Bintarini, Marhaeni \& Lasmawan (2013) bahwa pemanfaatan lingkungan sekitar yang dekat dengan peserta didik memiliki efektifitas yang tinggi dalam menunjang keberhasilan pembelajaran. Mahasiswa akan lebih mudah membuat konsep dengan menyatukan pengalaman yang sudah mereka miliki sebelumnya dengan pengatahuan baru yang mereka dapat dari berbagai referensi.

Keaktifan mahasiswa selama menggunakan learning cycle berdampak pada peningkatan pemahaman konsep. Hal ini ditunjukkan dengan meningkatkan jumlah mahasiswa yang tuntas saat tahap evaluation. Pada siklus I, 41,3\% mahasiswa tuntas dalam belajar dan 58,7 $\%$ mahasiswa tidak tuntas dalam belajar. Pada siklus II 100\% mahasiswa tuntas.

Peningkatan pemahaman konsep juga terlihat dari meningkatnya nilai rata-rata hasil belajar setiap siklusnya. Nilai rata-rata hasil belajar untuk pretest sebesar 33,89 , nilai ratarata hasil belajar untuk siklus I sebesar 62,93, dan nilai rata-rata hasil belajar untuk siklus II sebesar 92,54. Hal ini membuktikan bahwa learning cycle 5E mampu meningkatkan pemahaman konsep mahasiswa seiring dengan meningkatkan hasil belajar mereka.

Hasil penelitian ini mampu menguatkan beberapa hasil penelitian sebelumnya yang membuktikan bahwa learning cycle mampu meningkatkan proses belajar seperti keaktifan mahasiswa, pemahaman konsep, dan hasil belajar. Hasil penelitian Rahayuningsih, Masykuri, \& Utami (2014) bahwa learning cycle 5E dapat meningkatkan kualitas proses yaitu keaktifan serta hasil belajar juga meningkat, hal ini ditunjukkan dari data ketuntasan belajar. Hasil penelitian Kulsum \& Hindarto (2011) yang menyimpulkan bahwa model learning cycle mampu meningkatkan keaktifan dan hasil belajar di setiap siklusnya. 


\section{Simpulan}

Berdasarkan pembahasan yang telah dilakukan dapat disimpulkan bahwa dengan penerapan model pembelajaran learning cycle dapat meningkatkan keaktifan dan pemahaman konsep IPS mahasiswa PGSD UAD, dengan penjelasan sebagai berikut: (1) Model pembelajaran learning cycle dapat meningkatkan keaktifan mahasiswa PGSD UAD. Hal ini ditunjukkan dengan peningkatan persentase keaktifan belajar yang diperoleh dari observasi. (2) Model pembelajaran learning cycle dapat meningkatkan pemahaman konsep IPS mahasiswa PGSD UAD. Hal ini ditunjukkan dengan peningkatan persentase pemahaman konsep yang diperoleh dari observasi juga diperkuat dengan peningkatan persentasi ketuntasan tes hasil belajar.

\section{Daftar Pustaka}

Abruscato, J., \& DeRosa Donald A. (2010). Teaching children science-a discovery approach $-7^{\text {ed }}$. Boston: Allyn\& Bacon.

Arikunto, S., Suhardjono, \& Supardi. (2007). Penelitian tindakan kelas. Jakarta: Bumi Aksara.

Baharuddin. (2009). Pendidikan dan psikologi perkembangan. Yogyakarta: Arruz Media.

Bintarini, N. K., Marhaeni \& Lasmawan, I. W. (2013). Determinasi pemanfaatan lingkungan sekitar sekolah sebagai sumber belajar terhadap gaya belajar dan pemahaman konsep IPS pada siswa kelas IV SDN Gugur Yudistira Kecamatan Negara. E-journal Pascasarjana UNDIKSA, 3, 1-11. Laman web pasca.undiksha.ac.id/e-

journal/index.php/jurnal_pendas/article/v iew/602 [diakses 25 Mei 2016]

Bybee, R.W. (2006). The BSCS 5E. Instructional model: Origins and effectiveness. Laman web http://www.hscs.org/site/default/files/BS CS_5E_Instructional_Model-

Full_Report.pdf [diakses 20 Maret 2014].

Chiapepetta \& Koballa, Jr. (2010). Science instructional in the middle and secondary schools. Boston: Allyn \& Bacon.

Ghozali, I. (2009). Aplikasi analisis multivariate dengan program SPSS. Semarang: Badan Penerbit UNDIP.
Kulsum, U \& Hindarto, N. (2011). Penerapan model learning cycle pada sub pokok bahasan kalor untuk meningkatkan keaktifan dan hasil belajar siswa kelas VII SMP. Jurnal Pendidikan Fisika Indonesia, 7, 128-133.

Mulyasa. (2005). Menjadi guru profesional. Bandung: PT Remaja Rosda Karya.

Noname. (2014). Activity four, engage, explore, explain, extend, evaluation. Laman web http://smartideas.wikispaces.com/Activit y+Two [diakses 12 November 2014]

Rahayuningsih, R., Masykuri, M., \& Utami, B. (2012). Penerapan siklus belajar 5E disertai peta konsep untuk meningkatkan kualitas proses dan hasil belajar kimia pada materi kelarutan dan hasil kali kelarutan kelas XI IPA SMA Negeri 1 Kartasura tahun pelajaran 2011/2012. Jurnal Pendidikan Kimia, 1 (1), 51-58.

Saputra, I.W.A., Wiyasa, I.K.N., \& Ardana, I.K. (2014). Model pembelajaran learning cycle berpengaruh terhadap hasil belajar IPA siswa kelas V gugus I Kecamatan Dawan. E-journal UNDIKSA, 2 (1),1-10. Laman web http://download.portalgaruda.org/article.p hp? article $=138639 \&$ val $=1342 \&$ title $=$ MO DEL\%20PEMBELAJARAN\%20LEAR NING\%20CYCLE\%20BERPENGARU H\%20TERHADAP\%20HASIL\%20BEL AJAR\%20IPA\%20SISWA\%20KELAS \%20VGUGUS\%20I\%20KECAMATAN \%20DAWAN [diakses 25 Mei 2016]

Sardiman. (2014). Interaksi dan motivasi belajar mengajar. Jakarta: PT Raja Grafindo Persada.

Setiawan, R. (2012). Masalah pendidikan di Indonesia dan solusinya. (online). Laman web

http://kampus.okezone.com/read/2012/10 /23/373/708090/indeks-pendidikan-rirendah-jangan-salahkan-mendikbud, [diakses 5 April 2013].

Sole, F., \& Wilujeng, I. (2013). Pengaruh implementasi the 4-e learning cycle terhadap pengetahuan, keterampilan proses dasar, dan sikap ilmiah IPA siswa SDK Kererobbo. Jurnal Prima Edukasia, 1(1), 43-50. Retrieved from http://journal.uny.ac.id/index.php/jp e/article/view/2315 
Jurnal Prima Edukasia, 4 (2), Juli 2016 - 162

Laila Fatmawati

Sugiyono. (2007). Metode Penelitian Bisnis. Bandung: CV. Alfabeta

Susanto, Y.A., Maftukhin, A., \& Ngazizah, N. (2014). Pengembangan LKS berbasis learning cycle untuk meningkatkan aktivitas belajar siswa di SMP N 15 Purworejo tahun ajaran 2013/2014. Jurnal Radiasi, 5(1), 42-48.

Wahyudi, I. (2012). Mengejar profesionalisme guru strategi praktis mewujudkan citra guru profesional. Jakarta: Prestasi Pustaka
Wahyuni, Z., Syamsu, S., \& Muslimin, M. (2013). Penerapan learning cycle tipe $5 E$ dengan media visual untuk meningkatkan hasil belajar fisika pada siswa kelas XC SMA Negerei 2 Dolo. Jurnal Pendidikan Fisika Tadulako, 1(1), 28-32.

Wenna, M. (2009). Strategi pembelajaran inovatif kontemporer: Suatu tinjauan konseptual operasional. Jakarta: Bumi Aksara. 